\section{TRENDS IN WORLD MILITARY EXPENDITURE, 2014}

SAM PERLO-FREEMAN, AUDE FLEURANT, PIETER D. WEZEMAN AND SIEMON T. WEZEMAN

Global military expenditure in 2014 was an estimated $\$ 1776$ billion, representing a marginal fall of about 0.4 per cent in real terms compared to $2013 .^{1}$ Total expenditure was equivalent to 2.3 per cent of global gross domestic product (GDP). This is the third consecutive year that total global military expenditure has decreased. However, the falls during the previous two years have been comparatively small; world military expenditure is still only 1.7 per cent below its 2011 peak, and it remains significantly above the levels of the late 1980s (see figure 1).

The pattern of the past few years-whereby military expenditure has fallen in the United States and Western Europe, but increased elsewherelargely continued in 2014, although spending in Latin America was essentially unchanged. Spending in Central Europe broke with recent trends and began to rise again following the large falls in previous years resulting from the global financial crisis that began in 2008. Africa, Asia, Eastern Europe

\footnotetext{
${ }^{1}$ Unless otherwise stated, dollar figures for national, regional or global military spending in 2014 refer to spending at current prices and exchange rates-i.e. converted from national currency to US dollars at the average market or official exchange rate for 2014. Figures for percentage changes between 2 years, unless otherwise stated, are given in 'real terms'-i.e. adjusted for inflation. The SIPRI Military Expenditure Database includes figures for each country and region in constant (2011) US dollars, which is the basis for the real-terms calculations. This means that local currency figures have first been adjusted for inflation in each country to express them in 2011 prices, then converted into US dollars at the average market or official exchange rate for 2011. Figures or rates of change in 'nominal' terms (US dollars or local currency) indicate figures that are not adjusted for inflation.
}

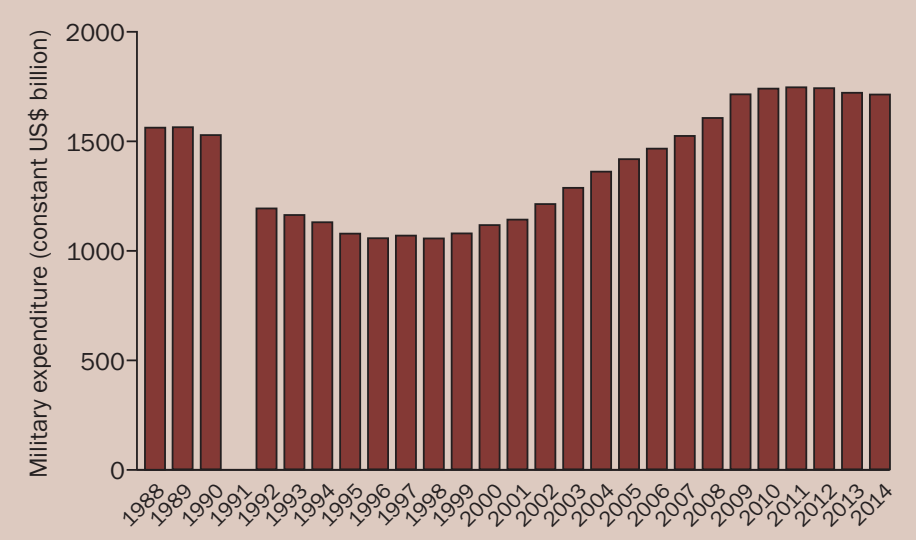

Figure 1. World military expenditure, 1988-2014

Note: The totals are based on the data on 172 states in the SIPRI Military Expenditure Database, <http://www.sipri.org/databases/milex/>. The absence of data for the Soviet Union in 1991 means that no total can be calculated for that year.

\section{KEY FACTS}

- Global military expenditure was $\$ 1776$ billion in 2014.

- Total spending fell by 0.4 per cent in real terms between 2013 and 2014, the third consecutive year of falling global spending.

- Overall military spending decreased in North America, Western and Central Europe, and Latin America and the Caribbean, but rose in Asia and Oceania, the Middle East, Eastern Europe and Africa.

- The five biggest spenders in 2014 were the USA, China, Russia, Saudi Arabia and France.

- Military expenditure in the USA fell by 6.5 per cent, to $\$ 610$ billion, as part of ongoing deficit reduction measures required by the US Budget Control Act of 2011.

- China, Russia and Saudi Arabia continued to make substantial increases in military expenditure. Saudi Arabia's 17 per cent increase was the highest of any country in the top 15 military spenders in 2014.

- A total of 20 countriesconcentrated in Africa, Eastern Europe and the Middle Eastspent more than 4 per cent of their GDP on the military in 2014, compared to 15 in 2013. Only 3 of the 20 countries are functioning democracies, and the majority were involved in armed conflict in 2013-14 or had a recent history of armed conflict. 
Table 1. The 15 countries with the highest military expenditure in 2014 Spending figures are in US\$, at current prices and exchange rates. Figures for changes are calculated from spending figures in constant (2011) prices.

\begin{tabular}{|c|c|c|c|c|c|c|}
\hline \multicolumn{2}{|l|}{ Rank } & \multirow[b]{2}{*}{ Country } & \multirow{2}{*}{$\begin{array}{l}\text { Spending, } \\
2014 \text { (\$ b.) }\end{array}$} & \multirow{2}{*}{$\begin{array}{l}\text { Change, } \\
2005-14 \\
(\%)\end{array}$} & \multicolumn{2}{|c|}{$\begin{array}{l}\text { Spending as a } \\
\text { share of GDP } \\
(\%)^{b}\end{array}$} \\
\hline 2014 & $2013^{a}$ & & & & 2014 & 2005 \\
\hline 1 & 1 & USA & 610 & -0.4 & 3.5 & 3.8 \\
\hline 2 & 2 & China & {$[216]$} & 167 & {$[2.1]$} & {$[2.0]$} \\
\hline 3 & 3 & Russia & {$[84.5]$} & 97 & {$[4.5]$} & [3.6] \\
\hline 4 & 4 & $\begin{array}{l}\text { Saudi } \\
\text { Arabia }\end{array}$ & 80.8 & 112 & 10.4 & 7.7 \\
\hline 5 & 5 & France & 62.3 & -3.2 & 2.2 & 2.5 \\
\hline 6 & 6 & UK & 60.5 & -5.5 & 2.2 & 2.4 \\
\hline 7 & 9 & India & 50.0 & 39 & 2.4 & 2.8 \\
\hline 8 & 8 & Germany & {$[46.5]$} & -0.8 & [1.2] & 1.4 \\
\hline 9 & 7 & Japan & 45.8 & -3.7 & 1.0 & 1.0 \\
\hline 10 & 10 & South Korea & 36.7 & 34 & 2.6 & 2.5 \\
\hline 11 & 12 & Brazil & 31.7 & 41 & 1.4 & 1.5 \\
\hline 12 & 11 & Italy & 30.9 & -27 & 1.5 & 1.9 \\
\hline 13 & 13 & Australia & 25.4 & 27 & 1.8 & 1.8 \\
\hline 14 & 14 & UAE & {$[22.8]$} & 135 & {$[5.1]$} & [3.7] \\
\hline 15 & 15 & Turkey & 22.6 & 15 & 2.2 & 2.5 \\
\hline \multicolumn{2}{|c|}{ Total top 15} & & 1427 & & & \\
\hline \multicolumn{2}{|c|}{ World total } & & 1776 & 21 & 2.3 & 2.4 \\
\hline
\end{tabular}

[] = SIPRI estimate.

a Ranks for 2013 are based on updated military expenditure figures for 2013 in the current edition of the SIPRI military expenditure database. They may therefore differ from the rankings for 2013 given in the SIPRI Yearbook 2014 and other SIPRI publications in 2014.

${ }^{b}$ The figures for military expenditure as a share of gross domestic product (GDP) are based on data from the International Monetary Fund (IMF) World Economic Outlook database, Oct. 2014. and the Middle East continued to see large increases. Excluding the USA, total military expenditure for the 'rest of the world' has increased continuously since 1998 and was up by 3.1 per cent in 2014 .

From 13 April 2015 the SIPRI Military Expenditure Database includes newly released information on military expenditure in 2014. This Fact Sheet describes the global, regional and national trends in military expenditure that are revealed by the new data, with a special focus on countries with a military burden-that is, military spending as a share of GDP-of over 4 per cent.

\section{THE TOP 15 MILITARY SPENDERS IN 2014}

There was no change in the countries that comprised the top 15 military spenders in 2014 compared to 2013 , although there were some changes in order (see table 1). India moved up from 9th position to 7th, exchanging places with Japan, while Brazil and Italy swapped places at 11th and 12th.

While the USA remains clearly the world's largest military spender, at nearly three times the level of second-placed China, its expenditure dropped by 6.5 per cent in 2014, largely as a result of budget deficit control measures put in place by the US legislature under the 2011 Budget Control Act. US military spending is expected to fall again in 2015 but at a slower rate.

Since reaching its highest recorded peak in 2010, US military expenditure has decreased by 19.8 per cent in real terms. The USA's share of world military expenditure remains high at 34 per cent, but it is declining steadily year on year as the USA reduces its spending and other states increase expenditure (see figure 2). Nevertheless, US military spending continues to run at historically high levels and is around the same level in real terms as at its previous peak in the late 1980s.

In 2014 China, Russia and Saudi Arabia were the second, third and fourth highest military spenders, respectively. China's expenditure rose by 9.7 per cent, Russia's spending was up 8.1 per cent and Saudi Arabia's by 17 per cent. China's military spending has generally kept pace with its economic growth rate, with military expenditure remaining, by SIPRI's estimate, a fairly steady share of GDP of between 2 per cent and 2.2 per cent over the past decade.

The huge increase in Saudi Arabia's spending is a reflection both of the continuing conflict and instability in the surrounding region, and of the revenues available to the government from the high price of oil that prevailed 
until late 2014. The drastic fall in oil prices in the latter part of 2014 may affect Saudi Arabia's ability to maintain these expenditure levels in the medium term. In the short term, however, Saudi Arabia can rely on its very large financial reserves to fund further spending. Meanwhile, Russia has already cut its planned military spending in 2015 by 5 per cent as a result of falling oil revenues, despite its involvement in the conflict in Ukraine and increasingly hostile relationship with the West. Russia's military budget for 2015 is nonetheless still around 15 per cent higher in real terms than spending in 2014.

Among other countries in the top 15, Australia also made a substantial increase in spending of 6.8 per cent, following three years of cuts, and there were small increases by India (1.8 per cent) and South Korea (2.3 per cent). Meanwhile, Italy's expenditure fell by 8.8 per cent; as Italy is one of the European countries experiencing economic difficulties due to the global financial crisis, its spending has now decreased by 25 per cent since the crisis began in 2008. There were smaller falls in the

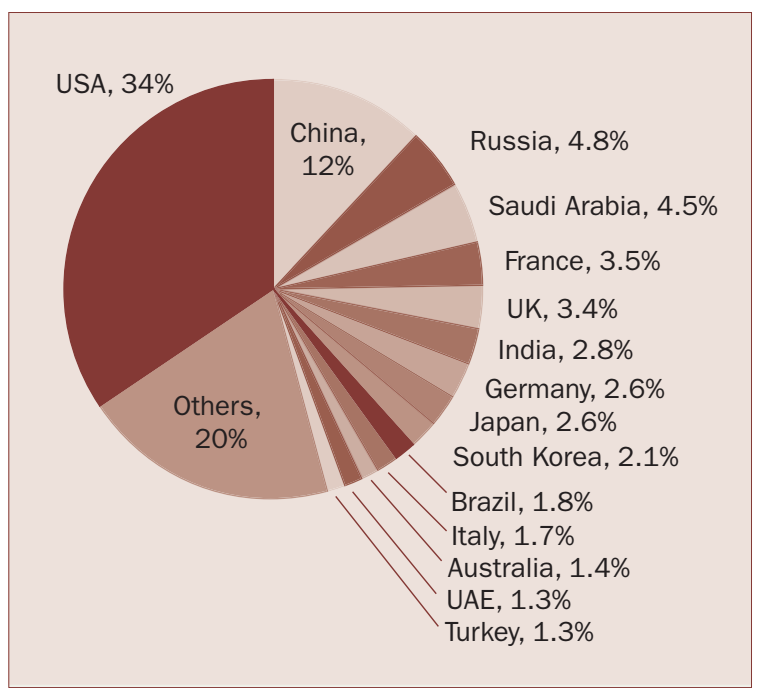

Figure 2. The share of world military expenditure of the 15 states with the highest expenditure in 2014 United Arab Emirates (UAE, 5.5 per cent), Germany (3.3 per cent) and Brazil (1.7 per cent), with very little change in France, the United Kingdom, Japan and Turkey.

\section{REGIONAL TRENDS}

\section{Asia and Oceania}

Military spending in Asia and Oceania increased by 5 per cent in 2014 and by 62 per cent between 2005 and 2014, reaching $\$ 439$ billion in 2014 at current prices and exchange rates (see table 2). In 2014 the growth of 9.7 per cent in China's expenditure dominated the regional trend, with the overall increase in the rest of the region standing at just 1.2 per cent.

Viet Nam also continued its rapid rise in military spending, with an increase of 9.6 per cent in 2014, reaching $\$ 4.3$ billion. Since 2005 Viet Nam's spending

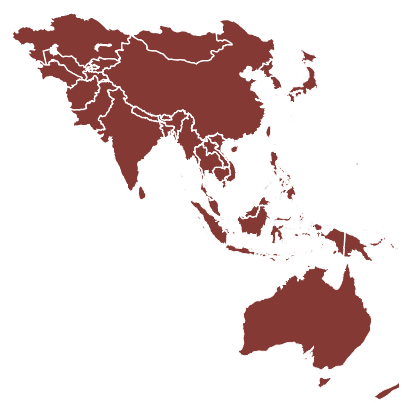
has risen by 128 per cent, reflecting tensions with China over territorial disputes in the South China Sea. However, Indonesia, another South China Sea littoral state, decreased its spending by 10 per cent in 2014-a reversal of recent trends, which may prove to be only temporary, given Indonesia's ambitious military modernization plans.

Although military spending in Asia and Oceania remains on an upward trend-with all states in the region except Fiji, Japan and Laos increasing their spending since 2005-the growth rate for most states has been substantially lower since 2009, when the effects of the global financial crisis began to be felt. For example, while China's military expenditure doubled in real terms between 2004-2009, it increased by only 48 per cent between $2009-14$. Likewise, while India's military expenditure increased by 45 per cent between 2004-2009, it has remained essentially flat since then, increasing by just 2 per cent. Overall, since 2009, three times as many countries in Asia

Table 2. Military expenditure in Asia and Oceania

\begin{tabular}{lccc} 
& \multirow{2}{*}{$\begin{array}{c}\text { Spending, } \\
\text { 2014 (\$ b.) }\end{array}$} & $2013-14$ & $2005-14$ \\
\cline { 3 - 4 } & 439 & 5.0 & 62 \\
Asia and Oceania & $439)^{a}$ \\
Central and South & 65.9 & 2.0 & 41 \\
$\quad$ Asia & & & \\
East Asia & 309 & 6.2 & 76 \\
Oceania & 28.0 & 6.9 & 26 \\
South East Asia & 35.9 & -0.4 & 45 \\
\hline
\end{tabular}

Major changes, 2013-14

\begin{tabular}{llll}
\hline Major increases & $\%$ & Major decreases & $\%$ \\
\hline Brunei & 29 & Indonesia & -10 \\
Afghanistan & 20 & Philippines & -2.4 \\
Cambodia & 14 & Sri Lanka & -2.0 \\
Kyrgyzstan & 10 & Taiwan & -1.9 \\
\hline
\end{tabular}

${ }^{a}$ Changes are in real terms. 


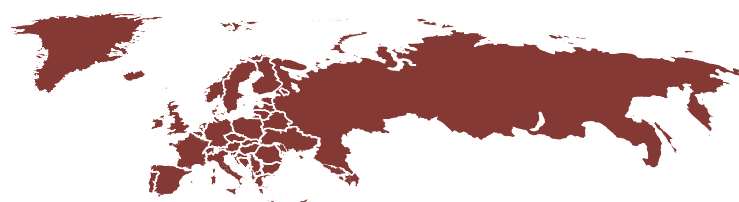

Table 3. Military expenditure in Europe

\begin{tabular}{lccc} 
& \multirow{2}{*}{\begin{tabular}{c} 
Spending, \\
\cline { 3 - 4 }
\end{tabular}} & \multicolumn{2}{c}{ Change $(\%)^{a}$} \\
\hline Europe & 386 & 0.6 & 6.6 \\
Eastern Europe & 93.9 & 8.4 & 98 \\
Western and & 292 & -1.9 & -8.3 \\
$\quad$ Central Europe & & & \\
\hline
\end{tabular}

Major changes, 2013-14

\begin{tabular}{llll}
\hline Major increases & $\%$ & Major decreases & $\%$ \\
\hline Ukraine & $(23)$ & Albania & -26 \\
Poland & 13 & Portugal & -12 \\
Russia & 8.1 & Greece & -11 \\
Lithuania & 6.0 & Italy & -8.8
\end{tabular}

()$=$ uncertain estimate.

${ }^{a}$ Changes are in real terms. and Oceania have slowed (or reversed) their rate of increase in military expenditure as have increased their rate of growth. In the region as a whole, the growth rate slowed from 41 per cent in the period 2004-2009, to 21 per cent in the period 2009-14.

\section{Europe}

Military expenditure in Europe increased by 0.6 per cent in 2014 , reaching $\$ 386$ billion see (table 3). The total was 6.6 per cent higher than in 2005. In Eastern Europe spending was up 8.4 per cent in 2014, reaching $\$ 93.9$ billion, while in Western and Central Europe the total was down 1.9 per cent at \$292 billion. Since 2005 Eastern European spendinghasincreased by 98 per cent, while that in Western and Central Europe has fallen by 8.3 per cent.

In Eastern Europe, SIPRI's provisional estimate for Ukraine's military spending in 2014 shows an increase of 23 per cent over 2013; this is much higher than the original budget estimates and is in response to the conflict in the east of country, which is probably still not fully accounted for in the latest figures. Russia's military spending also grew by 8.1 per cent to $\$ 84.5$ billion, but Russia had planned for this increase before the start of the crisis in Ukraine. Ukraine has doubled its budget for the armed forces in 2015 in real terms, while Russia also plans a rise of about 15 per cent.

In Western Europe the downward trend resulting from austerity policies continued in most countries in 2014. However, in Central Europe, Poland increased spending by 13 per cent, mostly due to its major military modernization programme for 2013-22. Several other countries in the subregion also raised expenditure, including the Baltic states, which have begun to reverse the heavy reductions in spending that followed the global financial crisis. Increases in many Central European countries, as well as some of the Nordic countries, are likely to continue in 2015 , in part as a reaction to the crisis in Ukraine (see SIPRI media briefing 'Military spending in Europe in the wake of the Ukraine crisis').

\section{The Middle East}

Military spending in the Middle East amounted to $\$ 196$ billion in 2014, an increase of 5.2 per cent over 2013, and 57 per cent since 2005 (see table 4). The largest increases since 2005 were by Iraq (286 per cent), the UAE (135 per cent), Bahrain (126 per cent) and Saudi Arabia (112 per cent). Figures for 2014 were not available for Kuwait, but its spending increased by 112 per cent between 2005 and 2013. All these countries are major oil producers, and their state revenues were boosted by high oil prices over the period. Military expenditure budgets of states in the region may be affected by the fall in the price of oil in late 2014, but any effects will likely be mitigated by the strong financial reserves built up by many countries following several years of high oil prices. 
In contrast, Turkey's spending grew by just 15 per cent since 2005, while Israel's military spending remained relatively stable throughout 2005-14. Based on data available, Israel's spending decreased by 8 per cent from 2013 to 2014; however, the final figure for 2014 is likely to be substantially higher as the current estimate may not fully cover the costs of the war in Gaza in 2014.

The last available figure for Qatar's military expenditure dates from 2010 when it stood at $\$ 1.9$ billion. However, Qatar started a major expansion of its armed forces in 2012 and announced orders for weapons worth $\$ 23.9$ billion dollars in 2014, suggesting a substantial increase in its military spending since 2010 .

\section{Latin America and the Caribbean}

Latin American military expenditure was essentially flat in 2014. Total military spending in South America was $\$ 67.3$ billion, down 1.3 per cent in real terms since 2013, but 48 per cent higher than in 2005; in Central America and the Caribbean the total was $\$ 10.4$ billion, up 9.1 per cent over 2013, and 90 per cent since 2005 (see table 5).

Brazil's military spending fell by 1.7 per cent, as the economy slowed and the government faced major social protests over the lack of basic services in the run-up to the 2014 soccer World Cup. GDP growth in 2014 was projected to be just 0.3 per cent, with only a slow recovery in 2015 to 1.4 per cent. Nonetheless, Brazil's spending was still 41 per cent higher than in 2005 and has continued on a fairly consistent, if uneven, upward trend since the mid1990s. This general increasing trend represents Brazil's ongoing military modernization programme. In 2014 this included the signing of a contract to purchase 36 combat aircraft from Sweden for $\$ 5.8$ billion.

Meanwhile, Mexico's military spending increased by 11 per cent in 2014 and has now more than doubled since 2005. A further rise of 10 per cent (8 per cent in real terms) is budgeted for 2015. Both military and security expenditure have increased rapidly as Mexico continues to use its armed forces, regular police and a newly created 5000-strong gendarmerie in its actions against drug cartels.

\section{Africa}

Africa once again saw the largest year-on-year increase in military expenditure of any region, at 5.9 per cent, reaching $\$ 50.2$ billion in 2014 (see table 6). Military spending in the region has increased by 91 per cent since 2005.

Africa's two biggest spenders, Algeria and Angola, continued their rapid military spending increases financed by high oil revenues, with Algeria increasing by 12 per cent to reach $\$ 11.9$ billion, and Angola by 6.7 per cent to hit $\$ 6.8$ billion. These countries have respectively trebled and doubled their spend-

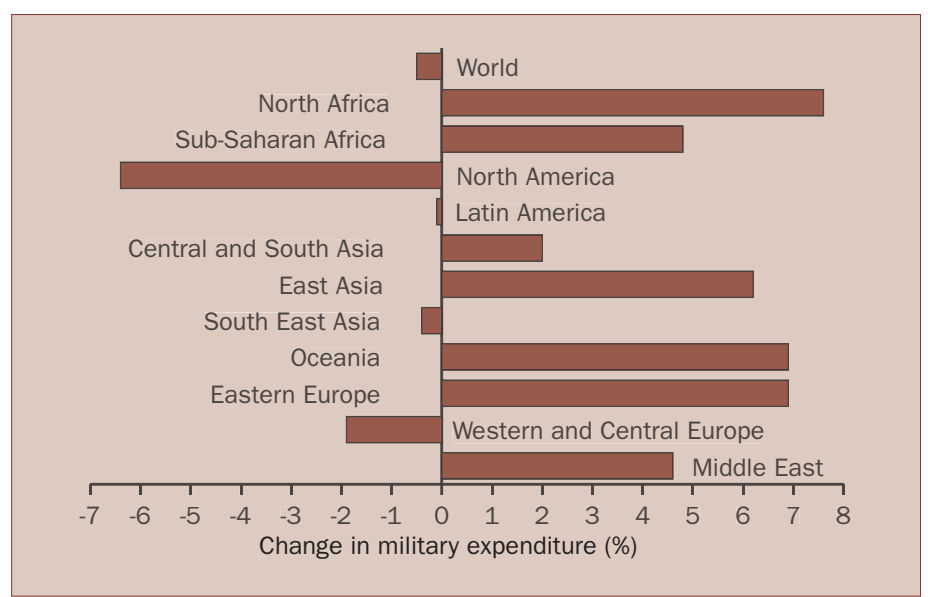

Figure 3. Changes in military expenditure, by region, 2013-14 
Table 6. Military expenditure in Africa

\begin{tabular}{lllc} 
& \multirow{2}{*}{\begin{tabular}{l} 
Spending, \\
\cline { 3 - 4 }
\end{tabular}} & \multicolumn{2}{l}{ Change (\%) ${ }^{a}$} \\
\hline 2014 (\$ b.) & $2013-14$ & $2005-14$ \\
Africa & $(50.2)$ & 5.9 & 91 \\
North Africa & 20.1 & 7.6 & 144 \\
Sub-Saharan & $(30.1)$ & 4.8 & 66 \\
$\quad$ Africa & & & \\
\hline
\end{tabular}

Major changes, 2013-14

\begin{tabular}{llll}
\hline Major increases & $\%$ & Major decreases & $\%$ \\
\hline Congo, Rep. & 88 & Malawi & -27 \\
Namibia & 47 & Nigeria & -9.3 \\
Zambia & 23 & Ghana & -5.8 \\
Guinea & 22 & Burundi & -5.0 \\
\hline
\end{tabular}

()$=$ uncertain estimate.

${ }^{a}$ Changes are in real terms. ing in real terms since 2005, and both now spend more than 5 per cent of their GDP on the military. It remains to be seen whether the crash in oil prices in late 2014 will halt this trend.

Nigeria's budgeted military expenditure fell in 2014 for the third year running, by 9.3 per cent, to $\$ 2.3$ billion. Nonetheless, the total is still 79 per cent higher than in 2005 , and the budgeted figure does not include a $\$ 1$ billion loan approved by the Nigerian Congress in October 2014 for military hardware and training to fight the militant group Boko Haram. However, it is debatable whether extra funding for the military on its own will prove effective, given the rampant corruption in the Nigerian armed forces and alleged human rights abuses by Nigerian soldiers that have alienated much of the local population. Such factors have severely impeded the fight against Boko Haram so far.

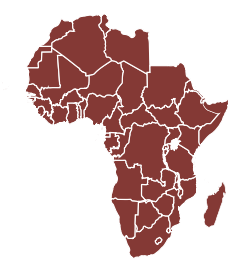

\section{COUNTRIES WITH HIGH MILITARY EXPENDITURE AS A SHARE OF GDP}

A country's military expenditure as a share of GDP-also known as the military burden-is the simplest measure of the relative economic burden the military places on the country. In general, most countries worldwide have seen a decline in their military burdens since the end of the cold war, although this trend has slightly reversed in recent years. In 2014 about 55 per cent of countries for which SIPRI had data had military burdens below 1.5 per cent of GDP.

However, there is very wide variation in military burdens, and in 2014 there was a sharp increase in the number of countries with military burdens over 4 per cent of GDP, as well as in countries with military burdens over 5 per cent. In total, 20 countries had military burdens over 4 per cent of GDP in 2014-or in the most recent year when data was available (2011 or later, see figure 4). Of these countries, 10 had military burdens over 5 per cent. ${ }^{2}$

The countries are very diverse in size (from Armenia with a population of 3 million to Russia with 143 million) as well as in absolute levels of military spending (from just $\$ 0.5$ billion to over $\$ 80$ billion in 2014). The Middle East is heavily over-represented, with 9 of the 20 countries in the list, including the top 2, representing a majority of the states in the region. There are 7 African countries, almost all of which have increased their military burden noticeably since 2005. Of the remaining countries, 3 are from Eastern Europe (Armenia, Azerbaijan and Russia) and 1 (Myanmar) is from Asia. In 2014, within Western and Central Europe, Serbia had the highest military burden at 2.3 per cent, and in the Americas the USA was the highest at 3.5 per cent.

By way of comparison, only 13 countries had a military burden over 4 per cent in 2005 (including Eritrea, for which data was not available in 2005, but which had a military burden of 21 per cent in 2003-the year closest to 2005 where comparable data was available). Burundi, Djibouti, Jordan, Kuwait and Singapore have fallen below 4 per cent of GDP since 2005.

\footnotetext{
2 There is no generally recognized figure for what constitutes a high military burden. The $4 \%$ threshold is chosen as one that has consistently represented at most the top quintile of military burdens for over 20 years.
} 
A common feature of the great majority of the countries in the list is a lack of effective democracy. The Polity IV dataset, produced by the Center for Systemic Peace, is one of the most widely used academic datasets for measuring levels of democracy and autocracy in different states since the early 19th century. Of the 20 countries in figure 4, only 3 (Israel, Lebanon and Namibia) were classed as 'democracies' in 2013 by Polity IV, although 56 per cent of countries worldwide were classed as such. Conversely, 6 out of the 20 , or 30 per cent, were classed as 'autocracies', compared to 13 per cent worldwide. Of the remaining 11, 2 (Libya and South Sudan) were classed as 'failed states', while 9 had a rating between democracy and autocracy (compared to 29 per cent of states worldwide).

Of the 20 countries, 11 were engaged in war or minor armed conflict in 2013 or 2014. Thus, while conflict was a common feature, it was not ubiquitous. However, several of the other countries have a recent history of conflict, often with continuing high tensions.

One country, Namibia, stands out as being a functioning democracy that has not suffered armed conflict since 1990, yet still has a military burden of 4.6 per cent. Namibia made a 66 per cent increase in its defence budget in 2014 to improve living conditions for its soldiers. Namibia's large geographical size and small population, which increases the relative cost of defending the country's long borders and coastline, may partly explain its relatively high military spending in the longer term.

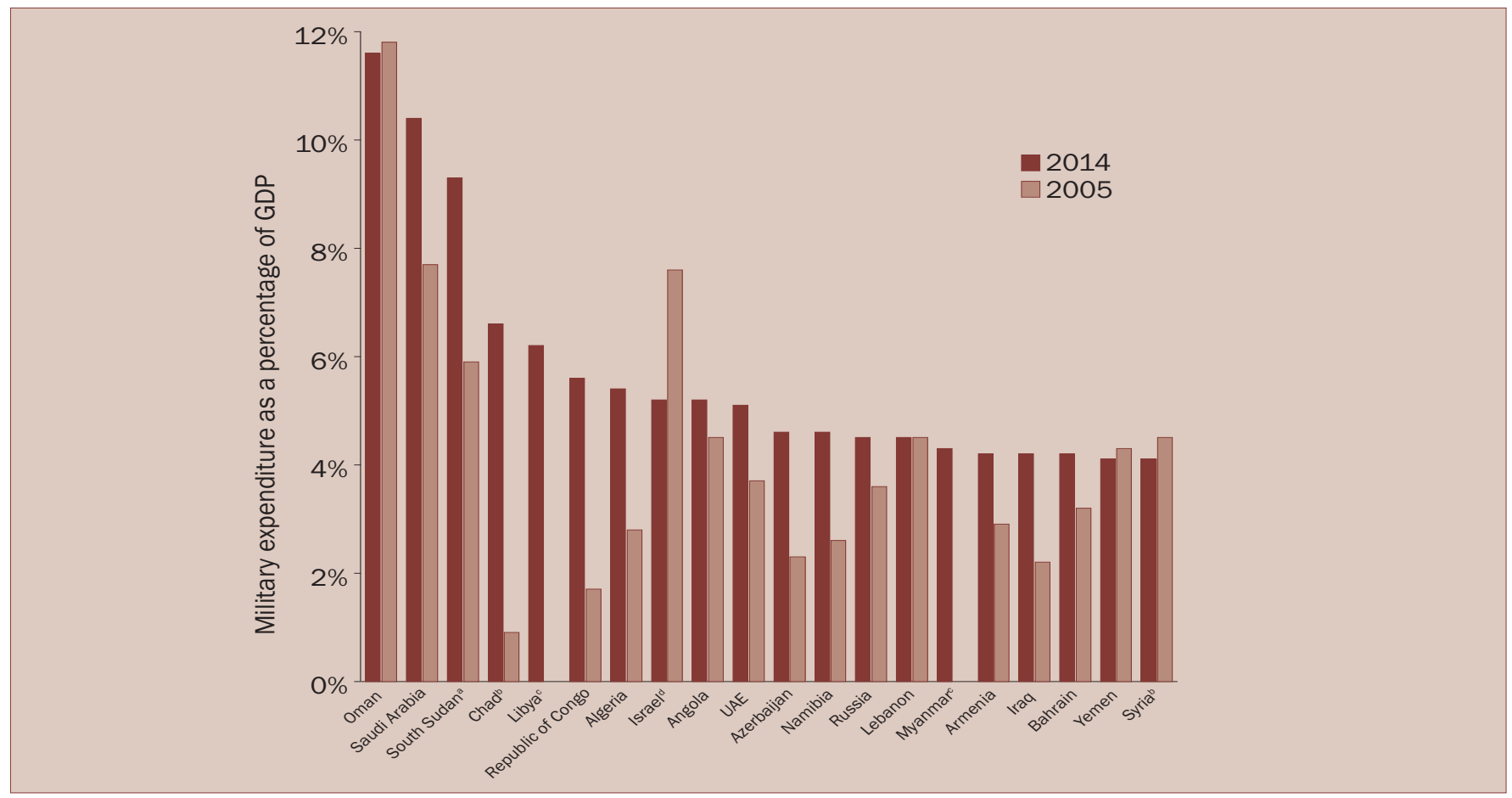

Figure 4. Countries with a military burden over 4 per cent of gross domestic product (GDP) in 2014 or in year of most recent available data

${ }^{a}$ The earlier figure for South Sudan is for 2006, not 2005, the earliest year of available data.

${ }^{b}$ The most recent available figures for Chad and Syria are from 2011.

${ }^{c}$ Data for Libya and Myanmar are available for 2005 but come from a different source of military expenditure data that is not directly comparable with the figures for 2014.

${ }^{d}$ The figures for Israel for 2014 may not fully include the cost of the war in Gaza.

Source: SIPRI Military Expenditure Database. 
SIPRI is an independent international institute dedicated to research into conflict, armaments, arms control and disarmament. Established in 1966, SIPRI provides data, analysis and recommendations, based on open sources, to policymakers, researchers, media and the interested public.

\section{GOVERNING BOARD}

Sven-Olof Petersson, Chairman (Sweden)

Dr Dewi Fortuna Anwar (Indonesia)

Dr Vladimir Baranovsky (Russia)

Ambassador Lakhdar Brahimi (Algeria)

Jayantha Dhanapala

(Sri Lanka)

Ambassador Wolfgang Ischinger (Germany)

Professor Mary Kaldor

(United Kingdom)

The Director

\section{DIRECTOR}

Dr Ian Anthony (United Kingdom)

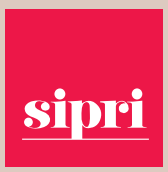

STOCKHOLM INTERNATIONAL PEACE RESEARCH INSTITUTE Signalistgatan 9 SE-169 70 Solna, Sweden Telephone: +4686559700 Fax: +4686559733

Email:sipri@sipri.org Internet: www.sipri.org

\section{THE SIPRI MILITARY EXPENDITURE DATABASE}

The SIPRI Military Expenditure Database provides military expenditure data by country for the years 1988-2014

- in local currency, at current prices,

- in US dollars, at constant (2011) prices and exchange rates,

- as a share (\%) of gross domestic product (GDP),

- per capita, in current US dollars, and

- as a share (\%) of general government expenditure.

SIPRI military expenditure data is based on open sources only, including a SIPRI questionnaire that is sent out annually to governments. The collected data is processed to achieve consistent time series which are, as far as possible, in accordance with the SIPRI definition of military expenditure.

The database is available at $<$ http://www.sipri.org/databases/milex/>.

\section{The definition of military expenditure}

Where possible, SIPRI military expenditure data includes all current and capital expenditure on

- the armed forces, including peacekeeping forces,

- defence ministries and other government agencies engaged in defence projects,

- paramilitary forces, when judged to be trained and equipped for military operations, and

- military space activities.

Such expenditure should include

- military and civil personnel, including retirement pensions of military personnel and social services for personnel,

- operations and maintenance,

- procurement,

- military research and development, and

- military aid (in the military expenditure of the donor country).

Civil defence and current expenditure on previous military activities-such as veterans' benefits, demobilization, conversion and weapon destructionare excluded.

\section{ABOUT THE AUTHORS}

Dr Sam Perlo-Freeman (United Kingdom) is a Senior Researcher with the SIPRI Arms and Military Expenditure Programme and Head of the Military Expenditure project.

Aude Fleurant (Canada/France) is Director of the SIPRI Arms and Military Expenditure Programme.

Pieter D. Wezeman (Netherlands/Sweden) is a Senior Researcher with the SIPRI Arms and Military Expenditure Programme.

Siemon T. Wezeman (Netherlands) is a Senior Researcher with the SIPRI Arms and Military Expenditure Programme. 